\title{
Zakonu Niemieckiego interpretatio Polonica. Uwagi o krzyżackim wątku dzieła naukowego Gerarda Labudy
}

Słowa kluczowe: Gerard Labuda, zakon krzyżacki, historiografia Keywords: Gerard Labuda, Teutonic Order, historiography

\begin{abstract}
This paper describes the approach of one of the greatest Polish medievalists, Gerard Labuda, to the question of the Teutonic Order and its role in the history of Poland and the whole Baltic region.
\end{abstract}

Gdy przy okazji zbiorczego wydania swoich najważniejszych prac poświęconych problematyce krzyżackiej Gerard Labuda pokusił się o krótkie podsumowanie historii badań nad zakonem krzyżackim i wkładu do nich polskiej nauki, stwierdził: „Obok tradycyjnej interpretatio Teutonica dziejów Zakonu pojawiła się ich interpre-

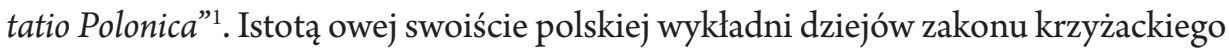
było dla uczonego wyjście poza model przedstawiania Zakonu skoncentrowany na państwowotwórczych i cywilizacyjnych osiągnięciach tego ostatniego i uwzględnienie przy jego ocenie również metod osiągania przezeń wytyczonych celów, a także ceny, jaką za wspomniane osiągnięcia przyszło zapłacić innym aktorom sceny dziejowej, przede wszystkim podbitym przez Zakon plemionom pruskim. Integralnym

1 G. Labuda, Studia krytyczne o początkach Zakonu Krzyżackiego w Prusach i na Pomorzu. Pisma wybrane, Poznań 2007, s. 6. 
elementem tego podejścia do problematyki krzyżackiej był również imperatyw obrony racji strony polskiej w jej dziejowych rozrachunkach z Zakonem.

G. Labuda konsekwentnie podążał tą drogą w swoich badaniach, których wątek przewodni, poczynając od debiutanckiej monografii z 1937 r. Polska i krzyżacka misja $w$ Prusach do połowy XIII wieku, stanowiła problematyka genezy państwa zakonnego w Prusach ${ }^{2}$. Zgodnie z generalną tendencją polskiej historiografii ${ }^{3}$ uczony uważał powstanie tego państwa za wydarzenie o zdecydowanie negatywnych konsekwencjach dla Polski i całego regionu nadbałtyckiego, z czego wynikała wyczuwalna w jego twórczości, i mająca również swoje analogie w polskiej historiografii, tendencja do swego rodzaju moralnej delegitymizacji tego państwa przez wykazanie, że u źródeł jego istnienia legły działania o przeniewierczym charakterze, wymierzone przede wszystkim w głównego sprawcę sprowadzenia Zakonu do Polski, księcia Konrada Mazowieckiego, oraz w misyjnego biskupa Prus Chrystiana. W tendencję tę wpisywała się również negatywna ocena stosunku Zakonu do kwestii chrystianizacji Prus.

Koncepcja „nieprawego pochodzenia” państwa zakonnego w Prusach przybrała najradykalniejszą postać w poglądach Wojciecha Kętrzyńskiego, który w swej klasycznej pracy $O$ powotaniu Krzyżaków przez ks. Konrada odrzucił tradycyjną wizję sprowadzenia Krzyżaków jako zapory przed najazdami Prusów na ziemie polskie i za rzeczywisty powód odwołania się przez księcia Konrada Mazowieckiego do usług Zakonu uznał dążenie polskiego władcy do podporządkowania Prus sobie samemu. Zgodnie z tą wizją fiasko planów Konrada - równoznaczne z pozbawieniem Polski szans na wchłonięcie ziem pruskich - było efektem wiarołomności Krzyżaków,

2 Tenże, Polska i krzyżacka misja w Prusach do połowy XIII wieku, Poznań 1937 (odbitka z Annales Missiologicae 9 [1937], s. 201-435); na temat dokonań uczonego w zakresie badań nad zakonem krzyżackim zob. T. Jasiński, Dzieje Zakonu Krzyżackiego w dorobku naukowym Gerarda Labudy, [w: ] Naukowe dzieło Profesora Gerarda Labudy, red. J. Dobosz, Poznań 2006, s. 111-120; zob. też M. Biskup, Gerard Labuda jako historyk Pomorza, Zap. Hist. 52 (1987), z. 4, s. 5-20, gdzie również szereg odniesień do krzyżackiego wątku badań G. Labudy.

3 Na temat oceny dziejowej roli Zakonu w polskiej historiografii zob. M. Biskup, Rola zakonu krzyżackiego w wiekach XIII-XVI, [w:] Stosunki polsko-niemieckie w historiografii, cz. 1, red. J. Krasuski, Poznań 1974, s. 327-361; tenże, Rola zakonu krzyżackiego w Prusach $w$ historii Polski, [w:] Zakon krzyżacki a Polska w średniowieczu. IV Konferencja Wspólnej Komisji Podręcznikowej PRL-RFN Historyków 16-22 IX 1973 r., Warszawa, V Konferencja Wspólnej Komisji Podręcznikowej PRL-RFN 19-23 IX 1974 r., Toruń, red. M. Biskup, Poznań 1987, s. 25-35. 
którzy bez skrupułów odwoływali się w stosunkach ze swym protektorem do „kłamstwa i szalbierstwa” („Lug i Trug”), dążąc za pomocą sfałszowanych dokumentów do uwolnienia się od jego zwierzchnictwa i zdobycia Prus na własne konto 4 .

Sam G. Labuda zapatrywał się na genezę państwa zakonnego w dalece bardziej wyważony sposób, dostrzegając wprawdzie w inicjatywie osadzenia Zakonu na polsko-pruskim pograniczu również zalążki ekspansywnych dążeń księcia Konrada Mazowieckiego względem Prus, ale kładąc główny nacisk na defensywny aspekt motywacji polskiego władcy ${ }^{5}$. Również w kwestii autentyczności dokumentów dotyczących sprowadzenia Zakonu do Polski reprezentował uczony znacznie bardziej umiarkowane stanowisko, uznając konsekwentnie za falsyfikat, w ślad za Maksem Perlbachem oraz większością polskiej historiografii, przede wszystkim tzw. przywilej kruszwicki księcia Konrada Mazowieckiego z czerwca 1230 r. $^{6}$

Negatywna ocena autentyczności tego dokumentu stanowi jeden z najważniejszych elementów stworzonej przez G. Labudę wizji początków państwa krzyżackiego, choć

4 W. Kętrzyński, O powołaniu Krzyżaków przez ks. Konrada, Kraków 1903; zob. zwł. tamże, s. 104-106; niemieckie wydanie tejże pracy: Der Deutsche Orden und Konrad von Masovien 1225-1235, Lemberg 1904; szerzej na temat kontrowersji wokół początków państwa zakonnego w Prusach piszę w artykule: Między Hilferuf a Lug i Trug - spór o interpretację początków państwa krzyżackiego $w$ Prusach $w$ historiografii XIX i pierwszej połowy XX wieku, Klio Polska. Studia i Materiały z Dziejów Historiografii Polskiej 12 (2020), s. 97-118.

5 G. Labuda, Polska i krzyżacka misja, s. 89-91; M. Biskup, G. Labuda, Dzieje zakonu krzyżackiego w Prusach. Gospodarka - Spoteczeństwo - Państwo - Ideologia, Gdańsk 1988 (1. wyd.: 1986), s. 10.

6 G. Labuda, Polska i krzyżacka misja, s. 145; tenże, Stanowisko ziemi chetmińskiej w państwie krzyżackim w latach 1228-1454, Przegl. Hist. 45 (1954), nr 2-3, s. 280-337, tu: s. 285-294 (to samo [w:] tegoż, Studia krytyczne, s. 103-174, tu s. 109-121); tenże, Die Urkunden über die Anfänge des Deutschen Ordens im Kulmerland und in Preußen in den Jahren 1226-1243, [w:] Die geistlichen Ritterorden Europas, hrsg. v. J. Fleckenstein, M. Hellmann, Sigmaringen 1980, s. 299-316, tu: s. 299 (to samo [w:] tegoż, Studia krytyczne, s. 213-231, tu: s. 213 n.); tenże, Über die angeblichen und vermuteten Fälschungen des Deutschen Ordens in Preußen, [w: Fälschungen im Mittelalter. Internationaler Kongreß der Monumenta Germaniae Historica München, 16.-19. September 1986, Teil IV Diplomatische Fälschungen (II), Hannover 1988, s. 499-521, tu: s. 508-512 (to samo [w:] tegoż, Studia krytyczne, s. 249-269, tu: s. 257-261); tenże, Über die Urkunden zur Gründung des Deutschen Ordens im Kulmerlande und im Preussen in den Jahren 1226-1234, [w:] Die Ritterorden zwischen geistlicher und weltlicher Macht im Mittelalter, hrsg. v. Z.H. Nowak, Torun 1990 (Ordines militares. Colloquia Torunensia Historica V), s. 21-44, tu: s. 27-31 (to samo [w:] tegoż, Studia krytyczne, s. 189-211, tu: s. 196-201); tenże, Epilog dyskusji o poczatkach Zakonu Krzyżackiego w ziemi chetmińskiej i w Prusach, [w:] tegoż, Studia krytyczne, s. 271-298, passim; zob. też M. Biskup, G. Labuda, Dzieje zakonu krzyżackiego, s. 127. 
uczony wykazywał pewną chwiejność w interpretacji tego przywileju, nie mogąc się zdecydować, czy głównym celem jego sfabrykowania było uzyskanie przez Zakon pełni praw władczych w ziemi chełmińskiej, jak zwykła interpretować ów dokument historiografia, czy też raczej otwarcie sobie przez Zakon drogi do podporządkowania Prus. Chwiejność tę obrazuje najlepiej obszerne studium uczonego z 1954 r. na temat statusu ziemi chełmńskiej w państwie krzyżackim. Z jednej strony G. Labuda dowodził w nim, iż zapisy przywileju kruszwickiego dotyczące ziemi chełmińskiej nie dawały Zakonowi nic ponad to, co ten uzyskał już na mocy wcześniejszych, autentycznych nadań Konrada Mazowieckiego, niewyłączających ziemi chełmińskiej spod zwierzchniej władzy księcia, a także, że właściwym motywem stworzenia przez Zakon tego falsyfikatu było dążenie do pozyskania Prus. Z drugiej jednak strony rozwinął szeroką argumentację przeciwko tezie ,jakoby aktem tym książę mazowiecki dobrowolnie wyłączał tę ziemię z granic państwa polskiego", co implikuje wszak postrzeganie przywileju kruszwickiego jako aktu o takiej właśnie wymowie, sfabrykowanego z myślą o zapewnieniu Zakonowi całkowicie niezależnej pozycji w ziemi chełmińskiej ${ }^{7}$. W kilku swych późniejszych pracach G. Labuda skłaniał się raczej ku interpretowaniu powodów spreparowania przywileju kruszwickiego przez pryzmat zawartych w nim zapisów dotyczących przyszłych zdobyczy Zakonu w Prusach ${ }^{8}$. Jednak w swej ostatniej pracy dotykającej kwestii autentyczności tego przywileju powrócił niejako na klasyczne pozycje historiografii, interpretując ów rzekomy w jego opinii przywilej Konrada Mazowieckiego jako narzędzie mające służyć wyrugowaniu wpływów księcia z ziemi chełmińskiej9.

Jedną z okoliczności demaskujących nieautentyczność przywileju kruszwickiego była w opinii Labudy treść porozumień zawartych przez biskupa Prus Chrystiana z Krzyżakami wiosną 1231 r., a przewidujących odstąpienie Krzyżakom przez Chrystiana trzeciej części Prus. Zdaniem uczonego układ taki nie miałby racji bytu, gdyby Krzyżacy rzeczywiście, jak głosi przywilej kruszwicki, mieli w czerwcu 1230 r. otrzymać od księcia Konrada Mazowieckiego darowiznę całych Prus ${ }^{10}$. Podobne wnioski

7 G. Labuda, Stanowisko ziemi chetmińskiej, s. 287-290, cytat na s. 289 (to samo [w:] tegoż, Studia krytyczne, s. 112-115, cytat na s. 114).

8 M. Biskup, G. Labuda, Dzieje zakonu krzyżackiego, s. 126 n.; G. Labuda, Über die angeblichen und vermuteten Fälschungen, s. 508-512 (to samo [w:] tegoż, Studia krytyczne, s. 257-261); tenże, Über die Urkunden zur Gründung, s. 27-31 (to samo [w:] tegoż, Studia krytyczne, s. 196$-201)$.

9 Tenże, Epilog dyskusji, s. 287.

10 Tenże, Stanowisko ziemi chetmińskiej, s. 290 n. (to samo [w:] tegoż, Studia krytyczne, s. 115-117). 
uczony wyciągnął z układu pomiędzy Krzyżakami a księciem Konradem Mazowieckim z 19 X 1235 r. kończącego spór wywołany przez samowolną inkorporację przez Krzyżaków zakonu dobrzyńskiego i zawierającego klauzule sugerujące posiadanie przez księcia Konrada Mazowieckiego po roku 1230, w którym książę miał rzekomo wystawić przywilej kruszwicki, określonych uprawnień władczych w ziemi chełmińskiej ${ }^{11}$. Uczony był również zdania, że na niekorzyść przywileju kruszwickiego przemawia odmienność zarysowanego w tymże dokumencie obrazu relacji Krzyżaków z księciem Konradem Mazowieckim od obrazu zawartego we wcześniejszym o pół roku tzw. dokumencie chełmińskim Konrada, w którym Krzyżacy zostali przedstawieni jako siła podporządkowana księciu, nie zaś, jak w przywileju kruszwickim, siła całkowicie odeń niezależna i wyświadczająca mu poniekąd dobrodziejstwo przez podjęcie walki z Prusami ${ }^{12}$. G. Labuda wskazywał wreszcie na klauzulę przywileju kruszwickiego mówiącą o darowaniu Krzyżakom przez księcia Konrada wszystkiego, co ci pierwsi mieli własnym wysiłkiem zdobyć w Prusach. Otóż zdaniem uczonego w autentycznym dokumencie księcia Konrada Mazowieckiego zapis taki nie miałby racji bytu, skoro książę nie posiadał żadnych tytułów prawnych do dysponowania ziemiami pruski$\mathrm{mi}^{13}$.

Jak dowodził uczony w swojej ostatniej publikacji odnoszącej się do kwestii autentyczności tego dokumentu z 2007 r., książę Konrad Mazowiecki miał się dowiedzieć o istnieniu przywileju kruszwickiego prawdopodobnie dopiero w kontekście swego sporu z Zakonem o ziemię dobrzyńską w 1235 r. Wtedy też - w zamian za ustąpienie przez Zakon z tego terytorium - miał zaakceptować wynikającą ze swego rzekomego przywileju pełną niezależność Zakonu w ziemi chełmińskiej. G. Labuda uznał to za całkowitą klęskę Konrada, mówiąc o jego „wydziedziczeniu” przez Krzyżaków z posiadanych praw oraz podkreślając dezorientację księcia co do rzeczywistych celów krzyżackich działań i służących realizacji tych celów metod ${ }^{14}$. Taki sposób przedstawienia okoliczności usadowienia się Krzyżaków w ziemi chełmińskiej

\footnotetext{
11 Tamże, s. 305 (to samo [w: ] tegoż, Studia krytyczne, s. 134).

12 Tenże, Über die angeblichen und vermuteten Fälschungen, s. 511 (to samo [w:] tegoż, Studia krytyczne, s. 260); tenże, Über die Urkunden, s. 29 n. (to samo [w:] tegoż, Studia krytyczne, s. 199 n.).

13 Tenże, Über die angeblichen und vermuteten Fälschungen, s. $511 \mathrm{n}$. (to samo [w:] tegoż, Studia krytyczne, s. 260 n.); tenże, Über die Urkunden, s. 30 (to samo [w:] tegoż, Studia krytyczne, s. 200).

14 Tenże, Epilog dyskusji, s. 293-298; tamże, s. 298: „prawdopodobnie dopiero wtedy Konrad zdał sobie sprawę, co się stało poza jego plecami w ziemi chełmińskiej”.
} 
nasuwa nieodparte skojarzenia z wizją nakreśloną ongiś przez Wojciecha Kętrzyńskiego, do której nigdy wcześniej G. Labuda nie nawiązał w równie wyrazisty sposób.

Kwestia autentyczności przywileju kruszwickiego stanowiła jednak dla uczonego nie tylko klucz do zrozumienia taktyki Zakonu w jego zabiegach o niezależność w ziemi chełmińskiej i podporządkowanie sobie Prus, lecz także przyczynek do wyjaśnienia bodaj najważniejszego dlań zagadnienia wiążącego się z genezą państwa krzyżackiego nad Bałtykiem, jakim były prawne podstawy panowania Zakonu na zajętych przezeń terenach ${ }^{15}$. W swoim obszernym studium z 1954 r. na temat statusu ziemi chełmińskiej w ramach państwa krzyżackiego G. Labuda dowodził, że w świetle autentycznych dokumentów nadawczych księcia Konrada Mazowieckiego dla Zakonu dotyczących ziemi chełmińskiej ta ostatnia nie przestawała podlegać zwierzchniej władzy księcia i w sensie publicznoprawnym nadal stanowiła część ziem polskich ${ }^{16}$. W opinii uczonego sugerowane przez przywilej kruszwicki oddanie Zakonowi pełni uprawnień władczych w ziemi chełmińskiej nie było możliwe ani na gruncie zachodnioeuropejskiego prawa lennego (Zakon nie miał bowiem sprawności lennej), ani też na gruncie prawa polskiego, gdyż Konrad Mazowiecki nie mógłby dokonać pełnej alienacji cząstki piastowskiego patrymonium bez zgody innych członków dynastii piastowskiej ${ }^{17}$.

Związku ziemi chełmińskiej z resztą ziem polskich w niczym nie nadwerężały również Złota Bulla Fryderyka II, ani bulla protekcyjna papieża Grzegorza IX z 3 VIII 1234 r. W obu przywilejach została wszak przeprowadzona wyraźna linia podziału pomiędzy ziemiami pruskimi, których dotyczyły normatywne postanowienia obu dokumentów, a ziemią chełmińską, w odniesieniu do której oba dokumenty ograniczyły się jedynie do potwierdzenia nadań poczynionych tamże na rzecz Zakonu przez księcia Konrada Mazowieckiego ${ }^{18}$. W opinii Labudy dopiero pokój kaliski z 1343 r. z zawartym w nim potwierdzeniem przez Kazimierza Wielkiego

15 Por. M. Biskup, Gerard Labuda, s. 14 n.

16 G. Labuda, Stanowisko ziemi chetmińskiej, s. 282, 303-306 (to samo [w:] tegoż, Studia krytyczne, s. 106, 132-135).

17 Tenże, Stanowisko ziemi chetmińskiej, s. 288 n. (to samo [w:] tegoż, Studia krytyczne, s. 113-115); por. tenże, Die Urkunden, s. 308, przyp. 21 (to samo [w:] tegoż, Studia krytyczne, s. 222 n., przyp. 21); M. Biskup, G. Labuda, Dzieje zakonu krzyżackiego, s. 121.

18 G. Labuda, Stosunek prawnopubliczny Zakonu Krzyżackiego do Rzeszy Niemieckiej $w$ świetle Złotej Bulli Fryderyka II z roku 1226, Czasopismo Prawno-Historyczne 3 (1951), s. 87-124, tu: s. 96-98 (to samo [w:] tegoż, Studia krytyczne, s. 55-87, tu s. 63 n.); tenże, Stanowisko ziemi chetmińskiej, s. 297-303 (to samo [w:] tegoż, Studia krytyczne, s. 124-132); por. T. Jasiński, Dzieje, s. 114. 
niegdysiejszej darowizny ziemi chełmińskiej na rzecz Zakonu realnie zagroził publicznoprawnemu związkowi ziemi chełmińskiej z resztą ziem polskich ${ }^{19}$. Pomimo owej konfirmacji status ziemi chełmińskiej jako części państwa polskiego nie został jednak podważony skutecznie, skoro w ślad za wspomnianą darowizną nie poszło rozciągnięcie na ziemię chełmińską papieskiej protekcji, stanowiącej od $1234 \mathrm{r}$. prawny fundament panowania krzyżackiego w Prusach. W efekcie ziemia ta miała się znaleźć w swoistej próżni prawnej i fundamentem jej przynależności do krzyżackiego organizmu państwowego była wyłącznie okresowa koniunktura polityczna, tym zaś, co w opinii uczonego dodatkowo relatywizowało postanowienia pokoju kaliskiego, było zapisane w jego akcie uzależnienie trwałości jego postanowień od zachowania pokoju pomiędzy stronami ${ }^{20}$. Skoro więc ziemia chełmińska nigdy nie przestała być w sposób niepodważalny częścią ziem polskich, jej inkorporacja w roku 1454 była naturalnym aktem jej reintegracji z państwem polskim, co wyraził uczony za pomocą sugestywnego stwierdzenia: „W taki to sposób historia sama prostowała to, co w pewnym momencie doznało skrzywienia" ${ }^{21}$. G. Labuda podkreślał, że związki ziemi chełmińskiej z resztą ziem polskich nie uległy zatarciu również $\mathrm{w}$ wymiarze świadomościowym, wskazując w tym kontekście na treść zeznań licznych świadków w procesie polsko-krzyżackim z 1339 r., ujawniających obok przekonania o przynależności ziemi chełmińskiej do Królestwa Polskiego również pogląd o jedynie czasowym charakterze nadania Krzyżakom tejże ziemi przez Konrada Mazowieckiego ${ }^{22}$.

W powyższej koncepcji nietrudno dostrzec wpływ atmosfery lat powojennych, a także przejaw ogólniejszej cechy twórczości historiograficznej G. Labudy, jaką było uwrażliwienie na problem integralności ziem polskich i kwestię ścierania się na przestrzeni wieków żywiołu polskiego, względnie słowiańskiego, z żywiołem niemieckim ${ }^{23}$. W oczach uczonego losy ziemi chełmińskiej stanowiły bowiem jedynie fragment ogólniejszego procesu dezintegracji i reintegracji państwa polskiego, który - jak pisał w omawianym studium - „na granicy zachodniej został zamknięty dopiero w roku $1945^{224}$.

19 Tenże, Stanowisko ziemi chetmińskiej, s. 328 (to samo [w:] tegoż, Studia krytyczne, s. 163).

20 Tamże, s. 327 n. (to samo [w:] tegoż, Studia krytyczne, s. 162 n.).

21 Tamże, s. 333 (to samo [w:] tegoż, Studia krytyczne, s. 169).

22 Tamże, s. 314-326 (to samo [w:] tegoż, Studia krytyczne, s. 146-160).

23 Por. W. Wrzesiński, Polskie Ziemie Zachodnie i Pótnocne w historycznej twórczości naukowej Gerarda Labudy, [w:] Naukowe dzieło, s. 143-159.

24 G. Labuda, Stanowisko ziemi chetmińskiej, s. 281 (to samo [w:] tegoż, Studia krytyczne, s. 104). 
W tym miejscu należy wszakże odnotować, iż poglądy G. Labudy na prawny status ziemi chełmińskiej w okresie jej pozostawania pod rządami zakonu krzyżackiego uległy z biegiem czasu ewolucji. Umieszczenie przez uczonego rozprawy z 1954 r. w niezmienionej postaci i bez żadnego komentarza w zbiorczym wydaniu własnych prac dotyczących zakonu krzyżackiego z 2007 r. mogłoby sugerować, że na przestrzeni półwiecza, jakie upłynęło od pierwszej publikacji, w jego poglądach na publicznoprawny status ziemi chełmińskiej w okresie panowania Zakonu nie zaszły zasadnicze zmiany. Jednak w świetle napisanego przezeń specjalnie na potrzeby tomu z 2007 r. nowego tekstu odnoszącego się do problematyki osadzenia Zakonu w ziemi chełmińskiej należy ocenić tę sprawę inaczej. Otóż G. Labuda wysunął w rzeczonej pracy pogląd, że na mocy ugody z księciem Konradem Mazowieckim z 1235 r. w sprawie ziemi dobrzyńskiej, zakładającej oddanie Zakonowi w zamian za zwrot księciu tejże ziemi pełni uprawnień zwierzchnich w ziemi chełmińskiej, Zakon stał się „pełnoprawnym, suwerennym, podlegającym jedynie jurysdykcji protekcyjnej Stolicy Apostolskiej" władcą tego ostatniego terytorium ${ }^{25}$. Tym samym uczony w istocie zaprzeczył głównej tezie swego studium z 1954 r., zgadzając się, że w okresie rządów krzyżackich, i to już u ich zarania, ziemia chełmińska została skutecznie pod względem publicznoprawnym odłączona od reszty ziem polskich ${ }^{26}$.

Do pewnego stopnia podobną ewolucję przeszły poglądy G. Labudy na prawne podstawy panowania Zakonu na zaanektowanym przez niego w latach 1308-1309 Pomorzu Gdańskim. O ile wcześniej podkreślał uczony wątłość prawnych podstaw wykupu przez Zakon w latach 1309-1310 praw do Pomorza Gdańskiego od dysponujących „lepszymi prawami” do tejże ziemi margrabiów brandenburskich ${ }^{27}$, o tyle w jednej ze swych późnych prac zmienił zdanie. De facto usankcjonował on przyjętą przez Zakon w sporze z Polską o ziemie pomorskie linię obrony wspomnianej transakcji, wskazując jako praźródło uprawnień Zakonu do tego terytorium prawa zwierzchnie nabyte tam w roku 1300 przez króla Wacława II i scedowane w 1305 r. przez Wacława III na rzecz margrabiów brandenburskich ${ }^{28}$.

\footnotetext{
25 Tenże, Epilog dyskusji, s. 294.

26 Należy nadmienić, że wspomnianą tezę swego studium z 1954 r. podtrzymywał uczony także w swych późniejszych pracach; zob. tenże, Die Urkunden, s. 309 (to samo [w:] tegoż, Studia krytyczne, s. 224); M. Biskup, G. Labuda, Dzieje zakonu krzyżackiego, s. 121.

27 M. Biskup, G. Labuda, Dzieje zakonu krzyżackiego, s. 256-258.

28 G. Labuda, Podstawy polityczno-prawne kupna Pomorza Gdańskiego przez Zakon Krzyżacki od margrabiów brandenburskich $w$ latach 1309-1310, Roczn. Hist. 71 (2005), s. 31-61.
} 
Choć problem prawnego umocowania rządów krzyżackich miał dla G. Labudy szczególne znaczenie w odniesieniu do ziem polskich, to uczony przywiązywał do niego wagę również $\mathrm{w}$ odniesieniu do Prus. W tym wypadku jego poglądy pozostawały niezmienne: jako prawny fundament panowania Zakonu na ziemiach pruskich wskazywał konsekwentnie bullę protekcyjną Grzegorza IX dla Zakonu z 3 VIII 1234 r., czyniącą z opanowanych przez Zakon terenów pruskich obszar podporządkowany bezpośrednio Stolicy Apostolskiej i cedującą pełnię praw do tychże terenów na Zakon, stosownie do czego uczony zwykł określać ów dokument jako „magna charta" panowania Zakonu w Prusach ${ }^{29}$. Znaczenie bulli z 3 VIII 1234 r. zasadzało się, w opinii Labudy, na fakcie sprawowania przez papiestwo zwierzchnictwa nad Prusami już od początku misji biskupa Chrystiana, co czyniło z owej bulli akt realnie wpływający na sytuację prawną Zakonu na obszarze Prus ${ }^{30}$. To samo kryterium realności wpływów władz uniwersalnych w Prusach kazało uczonemu zachować wstrzemięźliwość w podkreślaniu znaczenia Złotej Bulli Fryderyka II z Rimini. G. Labuda widział bowiem w tym dokumencie nie tyle akt kładący prawne podwaliny pod panowanie Zakonu na ziemiach pruskich, ile wyraz programu politycznego zakładającego utworzenie tam suwerennego państwa krzyżackiego, podporządkowanego cesarstwu jedynie w ramach stosunku protekcji ${ }^{31}$.

W przekonaniu G. Labudy w takiej mierze, w jakiej bulla protekcyjna Grzegorza IX z 3 VIII 1234 r. stanowiła fundament panowania Zakonu w Prusach, była również klęską zamierzeń biskupa Prus Chrystiana, będącego w oczach uczonego drugim obok Konrada Mazowieckiego wielkim poszkodowanym w wyniku machinacji Za$\mathrm{konu}^{32}$. Labuda zwracał uwagę na bezwzględne wykorzystanie przez Zakon popad-

29 Tenże, Stanowisko ziemi chetmińskiej, s. 295-297 (to samo [w:] tegoż, Studia krytyczne, s. 121-124); tenże, Die Urkunden, s. 315 (to samo [w:] tegoż, Studia krytyczne, s. 230); zob. M. Biskup, G. Labuda, Dzieje zakonu krzyżackiego, s. 128: „Na tym polega główny sens bulli papieskiej z 1234 r. Konstytuowała ona autonomiczne państwo krzyżackie w Prusach”.

30 G. Labuda, Stosunek prawnopubliczny, s. 120 n. (to samo [w: tegoż, Studia krytyczne, s. 84 n.).

31 Tamże, s. 120-124 (to samo [w:] tegoż, Studia krytyczne, s. 83-87); zob. tenże, Die Urkunden, s. 315 (to samo [w: ] tegoż, Studia krytyczne, s. 230): „Am Anfang des Staates [państwa krzyżackiego - M.D.] steht somit nicht die Goldene Bulle des Kaisers, sondern die bleierne Bulle des Papstes".

32 Zob. zwł. G. Labuda, Podbój Prus w XIII wieku, [w:] Ekspansja niemieckch zakonów rycerskich $w$ strefie Battyku od XIII do połowy XVI wieku. Materiaty $z$ konferencji historyków radzieckich i polskich $w$ Toruniu z r. 1988, red. M. Biskup, Toruń 1990, s. 31-50, tu: s. 40 (to samo [w:] tegoż, Studia krytyczne, s. 37-53, tu: s. 46); uczony mówi tutaj o „przewrocie” 
nięcia Chrystiana w niewolę w 1233 r. jako okazji do eliminacji wpływów biskupa w Prusach, wskazując na to, że kluczową rolę odegrało w tym względzie wystaranie się przez Zakon o bullę z 3 VIII 1234 r. milcząco unieważniającą niemal dwudziestoletni dorobek misyjnego biskupstwa Prus ${ }^{33}$. Ostatecznym przypieczętowaniem klęski Chrystiana był zaś dokonany w 1243 r. podział Prus na diecezje. Poznański mediewista nie bez nuty goryczy podsumowywał:

Taki byl final piętnastoletnich zmagań o władztwo nad ziemią chełmińską i Prusami: zaczęło się w roku 1228 od daru ziemi chełmińskiej, a konkretnie grodu Chełmna, pod patronatem fundatora, księcia Konrada, a skończyło się całkowitym opanowaniem ziemi chełmińskiej i Prus nie tylko w aspekcie politycznoprawnym i kościelnym, lecz także rzeczowo ‘wydziedziczeniem’ zarówno księcia Konrada, jak i biskupa pruskiego Chrystiana ${ }^{34}$.

Równie krytycznie jak postawę Zakonu wobec księcia Konrada Mazowieckiego i biskupa Chrystiana G. Labuda oceniał stosunek Zakonu do zagadnienia samej misji. Najwięcej uwagi uczony poświęcił temu problemowi w swej debiutanckiej monografii z 1937 r., gdzie przedstawił misję pruską jako pole ścierania się dwóch tendencji: forsowanej przez papiestwo bez wyraźnych zamierzeń państwowotwórczych koncepcji chrystianizacji ostatnich pogańskich enklaw Europy oraz tendencji do wykorzystywania idei chrystianizacji jako narzędzia budowy własnych wpływów politycznych. Zgodnie z tym kluczem interpretacyjnym zakon krzyżacki pojawił się na polsko-pruskim pograniczu nie jako czynnik misyjny, ale stricte polityczny, mając jasno określony w Złotej Bulli z Rimini z 1226 r. program budowy w Prusach własnego państwa. Wprzęgnięcie Zakonu przez biskupa Prus Chrystiana we własne zamierzenia misyjne, dokonane na mocy porozumień biskupa z Krzyżakami w 1230 r., oraz niewiele późniejsze wyeliminowanie przez Zakon jego wpływów w Prusach, które stało się możliwe wskutek popadnięcia biskupa w wieloletnią

i „zamachu stanu” przeprowadzonym przez Krzyżaków w celu eliminacji wplywów Chrystiana w Prusach; zob. również tenże, Die Urkunden, s. 315 (to samo [w:] tegoż, Studia krytyczne, s. 230), gdzie w kontekście rozgrywki Chrystiana z Zakonem zostało przez Autora użyte (w cudzysłowie) pojęcie „wielkiej zdrady”, przy czym, co warte podkreślenia, Gerard Labuda uznał tutaj Chrystiana, a nie księcia Konrada Mazowieckiego za główną ofiarę machinacji Zakonu; zob. również tenże, Über die angeblichen und vermuteten Fälschungen, s. 520 (to samo [w:] tegoż, Studia krytyczne, s. 268).

33 Tenże, Polska i krzyżacka misja, s. 145-163; tenże' Die Urkunden, s. 314 n. (to samo [w: ] tegoż, Studia krytyczne, s. 229 n.); tenże, Über die angeblichen und vermuteten Fälschungen, s. 519 n. (to samo [w:] tegoż, Studia krytyczne, s. 267 n.).

34 Tenże, Epilog dyskusji, s. 295. 
niewolę u Prusów, pozwoliły jednak Zakonowi przejąć sztandar misji i zrealizować pod nim swe zamierzenia państwowotwórcze. Sukces ten nie szedł jednak w parze z realnymi postępami misji, którą Zakon traktował jedynie jako ideologiczny sztafaż dla brutalnej polityki podboju plemion pruskich, w istocie hamującej - co podkreślał Labuda dobitnie - ich rzeczywistą chrystianizację. W efekcie za jedyną bodaj zasługę Zakonu dla chrystianizacji ostatnich enklaw pogaństwa nad Bałtykiem uczony uznał dostarczenie przezeń mimowolnego impulsu do wykształcenia się po stronie polskiej alternatywnej koncepcji misji, zrealizowanej w postaci pokojowej chrystianizacji Litwy oraz na płaszczyźnie teoretycznej - wyrażonej w tezach Pawła Włodkowica ${ }^{35}$. Poglądom tym badacz pozostał wierny także na dalszych etapach swej naukowej drogi, wskazując także wówczas na instrumentalne traktowanie przez Zakon idei misyjnej i upominając się o pamięć o losie ofiar krzyżackiego podboju Prus $^{36}$.

Nie wszystkie spośród prac G. Labudy dotyczących zakonu krzyżackiego dają się wpisać w zastosowany w niniejszym artykule schemat interpretacyjny, akcentujący „polskość” przyjętej przez uczonego perspektywy badawczej. W niektórych z nich brak owej specyficznej nuty krytyki Zakonu, ujmowania się za poszkodowanymi w wyniku jego poczynań, względnie nuty obrony polskich racji dziejowych na gruncie stosunków Polski z Zakonem, jaka cechuje prace składające się na trzon dorobku uczonego w zakresie omawianej tu problematyki.

Charakterystycznych znamion takiej interpretacji dziejów zakonu krzyżackiego jest pozbawione obszerne hasło Krzyżacy, napisane przez Labudę do Encyklopedii Katolickiej ${ }^{37}$. Z oczywistych względów z sytuacją taką mamy do czynienia również w wypadku jedynej pracy uczonego niedotyczącej dziejów Zakonu w regionie nadbałtyckim, jaką jest późne studium poświęcone kwestii genezy niemieckiego bractwa szpitalnego z Ziemi Świętej. Labuda opowiedział się tu za wywiedzeniem początków tego bractwa z poświadczonego w pierwszej połowie XIII w. jerozolimskiego szpitala Niemców św. Marii ${ }^{38}$. Podobnie rzecz się ma w wypadku pracy uczonego poświęconej piętnastowiecznej tradycji o udziale hufca krzyżackiego pod

\footnotetext{
35 Tenże, Polska i krzyżacka misja, passim, zwł. s. 210-218; por. M. Biskup, Gerard Labuda, s. 6.

36 M. Biskup, G. Labuda, Dzieje zakonu krzyżackiego, s. 216-221, 225.

37 G. Labuda, Krzyżacy, [w:] Encyklopedia Katolicka, t. 10, Lublin 2004, kol. 55-62.

38 Tenże, Die Anfänge des Deutschen Ordens: In Jerusalem oder in Akkon?, Jahrbuch für die Geschichte Mittel- und Ostdeutschlands 52 (2006), s. 153-172 (to samo [w: ] tegoż, Studia krytyczne, s. 13-35).
} 
dowództwem wielkiego mistrza Poppona von Osternohe w bitwie pod Legnicą, w której G. Labuda podważył wiarygodność tej tradycji i w sposób przekonywający scharakteryzował mechanizm jej powstania ${ }^{39}$. Należy tu również wspomnieć artykuł uczonego o pomorsko-krzyżackim konflikcie granicznym z lat 1267/1268 ${ }^{40}$, czy wreszcie kilka prac o charakterze źródłoznawczym, w których uczony wnikał w skomplikowaną materię pruskiej tradycji annalistycznej, zajmował się źródłami Kroniki ziemi pruskiej Piotra z Dusburga, czy wreszcie starał się zidentyfikować autora Kroniki Oliwskiej ${ }^{41}$.

We wspomnianym wyżej schemacie interpretacyjnym znakomicie mieści się natomiast napisana przez G. Labudę wespół z Marianem Biskupem synteza dziejów zakonu krzyżackiego w Prusach, którą można z powodzeniem uznać za swoistą summę budowanej przez uczonego interpretatio Polonica dziejów Zakonu. Zmaterializowała się ona najpierw jako fragment szerzej zakrojonego przedsięwzięcia historiograficznego, jakim była Historia Pomorza, której pierwszy tom ukazał się w roku $1969^{42}$. W syntezie tej dzieje pruskiego państwa zakonu krzyżackiego zostały ukazane jako część dziejów Wielkiego Pomorza, ujmowanego jako ogół ziem rozciągających się między ujściem Odry i Niemna ${ }^{43}$. G. Labuda opracował tu dzieje państwa krzyżackiego do momentu zajęcia przez Zakon Pomorza Gdańskiego w latach 1308-1309, pozostawiwszy opracowanie późniejszego okresu M. Biskupowi. Synteza ta stała się podstawą wydanych w 1986 r. i powtórnie w 1988 r. przez obu uczonych Dziejów

39 Tenże, O udziale Krzyżaków i o śmierci wielkiego mistrza Zakonu Krzyżackiego Poppo von Osterna $w$ bitwie $z$ Tatarami pod Legnica $w$ roku 1241, Zap. Hist. 47 (1982), z. 4, s. 89-102 (to samo [w:] tegoż, Studia krytyczne, s. 89-101).

40 Tenże, Pomorsko-krzyżacki zatarg graniczny z roku 1267/1268. Przyczynek do migracji Prusów na Pomorze Gdańskie, Zap. Hist. 50 (1985), z. 2, s. 7-25.

${ }^{41}$ Tenże, O źródłach „Kroniki Pruskiej” Piotra z Dusburga (na marginesie pracy Marzeny Pollakówny, Kronika Piotra z Dusburga), Komunikaty Mazursko-Warmińskie 1971, nr 2-3, s. 217-243 (to samo [w:] tegoż, Studia krytyczne, s. 299-326; tam również „Posłowie” z 2006 r.; zob. s. 326-334); tenże, Studia nad annalistyka pomorska z XIII-XV wieku, Zapiski Towarzystwa Naukowego w Toruniu 20 (1954), z. 1-4, s. 101-138 (to samo [w:] tegoż, Studia krytyczne, s. 335-367); tenże, O opacie Stanistawie autorze Kroniki Oliwskiej z połowy XIV wieku, Komunikaty Mazursko-Warmińskie 1980, nr 1, s. 3-16 (to samo [w:] tegoż, Studia krytyczne, s. 369-384; tam również „Posłowie” z 2006 r.; zob. s. 384-395).

42 Historia Pomorza, t. 1: do roku 1466, red. G. Labuda, Poznań 1969; szerzej na temat tego przedsięwzięcia historiograficznego M. Biskup, Gerard Labuda, s. $10 \mathrm{n}$.

43 Na temat stworzonej przez G. Labudę koncepcji Wielkiego Pomorza zob. M. Biskup, Gerard Labuda, s. 7 n. 
zakonu krzyżackiego $w$ Prusach, gdzie tekst opublikowany już w ramach Historii Pomorza został znacząco poszerzony albo $\mathrm{w}$ drodze rozwinięcia poruszonych tam wątków, albo przez dodanie wątków zupełnie nowych ${ }^{44}$. Uzupełnienia te dotyczyły m.in. pozapruskich aspektów dziejów Zakonu, głównie w okresie poprzedzającym jego sprowadzenie do Polski, takich jak rozwój bazy organizacyjno-majątkowej Zakonu w Europie w początkach XIII w. czy kilkunastoletni epizod Zakonu w węgierskiej ziemi Borsa, w którym Labuda widział klucz do zrozumienia rozpoczętego niewiele później procesu sadowienia się Zakonu nad dolną Wisłą. Do nowych wątków należą też problematyka wewnętrznego funkcjonowania Zakonu w jego wymiarze instytucjonalnym, personalnym czy ideologicznym, a także kwestia wpływu niemieckiego zaplecza Zakonu na jego działalność w Prusach. Poza tym nieco dokładniej niż w Historii Pomorza została w omawianej syntezie przedstawiona problematyka podboju Prus przez Krzyżaków.

Tak zakrojone dzieło, które w 2000 r. ukazało się także w przekładzie na język niemiecki ${ }^{45}$, miało $\mathrm{w}$ zamyśle autorów dać całościowy obraz procesów politycznych, państwowotwórczych, społecznych, gospodarczych, ideologicznych i kulturowych, składających się na fenomen kolonialnego - jak expressis verbis określili je autorzy - państwa zakonu krzyżackiego w Prusach ${ }^{46}$. Elementem tego obrazu stała się także wyrazista ocena Zakonu jako władcy terytorialnego i podmiotu relacji międzynarodowych, akcentująca zaborczy charakter państwa zakonnego i wskazująca na sprzeczności pomiędzy religijno-ideologicznymi fundamentami instytucji Zakonu a praktyką jego funkcjonowania. Ducha tej oceny znakomicie oddaje następujące zdanie G. Labudy ze wstępu do Dziejów:

Działalność Zakonu odznaczała się jeszcze jedną osobliwością: był on mistrzem podwójnej gry. Lawirując przez cały czas swoich dziejów między papiestwem i cesarstwem, obie siły wprzęgał w obronę swoich interesów. Był twórcą czynów pozytywnych i postępowych o nieprzemijającym znaczeniu kulturowym, ale także czynów podstępnych i niegodnych, stawiających stale pod znakiem zapytania jego duchowny charakter ${ }^{47}$.

\footnotetext{
44 Por. M. Biskup, Gerard Labuda, s. 11 n.; T. Jasiński, Dzieje, s. 115.

45 M. Biskup, G. Labuda, Die Geschichte des Deutschen Ordens in Preußen. WirtschaftGesellschaft - Staat - Ideologie, przekł. J. Heyde, U. Kodur, Osnabrück 2000 (Deutsches Historisches Institut Warschau. Klio in Polen 6).

46 Ci sami, Dzieje zakonu krzyżackiego, s. 5.

47 Tamże, s. 10.
} 
Nie ulega wątpliwości, że tak jak wybicie się z początkiem XX w. historiografii polskiej do roli równorzędnego partnera historiografii niemieckiej w dyskusji nad dziejami zakonu krzyżackiego wzbogaciło obraz tych dziejów o niedostrzegane dotąd aspekty i dostarczyło wspomnianej dyskusji ożywczych impulsów, tak sam G. Labuda ze swą autorską wersją interpretatio Polonica zakonnych dziejów stał się jednym z najważniejszych uczestników owej debaty. W pewnym sensie programowa tendencyjność jego twórczości - unikająca jednak jaskrawych form i łatwo wytłumaczalna na tle polskich doświadczeń XX w. - w niczym nie umniejsza wartości jego dokonań, których główny walor stanowi ich stricte analityczny charakter, stanowiący najlepsze antidotum na upływ czasu i zmiany historiograficznych mód.

Niektóre elementy stworzonej przez G. Labudę interpretacji dziejów zakonu krzyżackiego nie wytrzymały rzecz jasna próby czasu. Z dzisiejszego punktu widzenia mocno anachroniczna wydaje się np. wizja Konrada Mazowieckiego jako biernej ofiary cynicznych gier Zakonu. Równie anachronicznie brzmią aluzje uczonego do „niewdzięczności” Zakonu wobec Polski ${ }^{48}$. W podobny sposób można też ocenić podszyte swego rodzaju „rewindykacyjną” tendencją przywiązanie uczonego do problematyki prawnych podstaw panowania Zakonu na zajętych przezeń terenach $^{49}$. Z drugiej strony jako na wskroś nowoczesną należy ocenić stworzoną przez G. Labudę wespół z M. Biskupem koncepcję syntezy dziejów Zakonu, zakładającą uwzględnienie nie tylko klasycznych zagadnień z obszaru dziejów politycznych, historii ustroju czy gospodarki, lecz także takich kwestii, jak skład społeczny Zakonu i jego społeczna baza, ideologiczne podstawy jego funkcjonowania czy mentalność jego członków. Dzięki takiemu ujęciu tematu dzieło to wniosło zupełnie nową jakość do historiografii dotyczącej zakonu krzyżackiego, pozostawiając daleko w tyle wszystkie dotychczasowe, polskie i obce, syntezy dziejów tego zakonu czy dziejów Prus. Zadecydowała o tym również dogłębność potraktowania w nim materii krzyżackich dziejów, pozwalająca czytelnikowi dotrzeć niejako do samych fundamentów wiedzy o faktach i zjawiskach składających się na fenomen Zakonu. To zapewne ten aspekt owego dzieła miał na myśli G. Labuda, gdy nazwał je „syntezą analityczną" ${ }^{0}$.

48 G. Labuda, Studia krytyczne, s. 6.

49 Ten aspekt zainteresowań G. Labudy odzwierciedla oprócz cytowanych powyżej prac również artykuł uczonego na temat okoliczności wydania Polsce dokumentów zawierających tytuły prawne zakonu krzyżackiego do ziem utraconych przezeń na mocy II pokoju toruńskiego; zob. G. Labuda, W sprawie wydania dokumentów krzyżackich Polsce w 1526 r., Zap. Hist. 21 (1955), z. 3-4, s. 184-200.

50 Tenże, Studia krytyczne, s. 6. 
Ów analityczny rys Dzieje zawdzięczają przede wszystkim wyeksponowaniu przez uczonego roli źródeł we własnym wykładzie, który jest prowadzony niejako w stałej konfrontacji tudzież w stałym dialogu z materiałem źródłowym.

Na tle powojennej historiografii dotyczącej zakonu krzyżackiego, zarówno polskiej, jak i niemieckiej, G. Labuda zajmuje - ze swym konsekwentnym przywiązaniem do problematyki genezy państwa krzyżackiego w Prusach oraz wczesnego okresu jego dziejów, a także niesłabnącą gotowością do weryfikowania źródłowych podstaw naszej wiedzy na ten temat - miejsce szczególne. Nie ulega wątpliwości, że nikt w polskiej historiografii nie zrobił więcej dla wyjaśnienia okoliczności usadowienia się zakonu krzyżackiego w ziemi chełmińskiej i w Prusach. Nikt też nie opisał w równie gruntowny sposób procesu kształtowania się zrębów państwa krzyżackiego w okresie pierwszych osiemdziesięciu lat po sprowadzeniu Zakonu do Polski. Tocząca się dyskusja czyni rzecz jasna tezy uczonego przedmiotem stałej weryfikacji, jednak niezależnie od tego, ile z owych tez przetrwa próbę czasu, badania G. Labudy będą stanowić zawsze jeden z głównych punktów odniesienia dla wszelkich usiłowań mających na celu zrozumienie fenomenu zakonu krzyżackiego i jego pruskiego państwa.

Nadesłany: 10 IX 2020

Nadesłany po poprawkach recenzyjnych: 11 VIII 2021

Zaakceptowany: 14 VIII 2021

Dr hab. Maciej Dorna, prof. UAM

Wydział Historii, Uniwersytet im. Adama Mickiewicza w Poznaniu

ul. Uniwersytetu Poznańskiego 7

61-614 Poznań

e-mail:m.dorna@amu.edu.pl

\section{Résumé}

Interpretatio Polonica of the Teutonic Order. Remarks on the Teutonic Knights Theme of Gerard Labuda's Research

This paper is an attempt to synthesise Gerard Labuda's studies on the history of the Teutonic Order and the history of its state formed upon the Lower Vistula. In this issue-based overview, the author indicates the main threads in Labuda's research and seeks to recognize both the elements of change and continuity in his views. The article identifies the dominant 
thread of Gerard Labuda's interest in the field, i.e., the origins of the state of the Teutonic Order in the Chełmno Land and Prussia and pinpoints those aspects of Labuda's historiographical work which reveal a desire to create an interpretation of the historical role of the Teutonic Order alternative to the German historiography.

Translated by Agnieszka Tokarczuk

\section{Biliografia/Bibliography}

Biskup M., Gerard Labuda jako historyk Pomorza, Zapiski Historyczne 52 (1987), z. 4, s. 5-20

Biskup M., Rola zakonu krzyżackiego w Prusach w historii Polski, [w: Z Zakon krzyżacki a Polska w średniowieczu. IV Konferencja Wspólnej Komisji Podręcznikowej PRL-RFN Historyków 16-22 IX 1973 r., Warszawa, V Konferencja Wspólnej Komisji Podręcznikowej PRL-RFN 19-23 IX 1974 r., Toruń, red. M. Biskup, Poznań 1987, s. 25-35

Biskup M., Rola zakonu krzyżackiego w wiekach XIII-XVI, [w: ] Stosunki polsko-niemieckie $w$ historiografii, cz. 1, red. J. Krasuski, Poznań 1974, s. 327-361

Biskup M., Labuda G., Die Geschichte des Deutschen Ordens in Preußen. Wirtschaft - Gesellschaft - Staat - Ideologie, przekł. J. Heyde, U. Kodur, Osnabrück 2000 (Deutsches Historisches Institut Warschau. Klio in Polen 6)

Biskup M., Labuda G., Dzieje zakonu krzyżackiego w Prusach. Gospodarka - Społeczeństwo - Państwo - Ideologia, Gdańsk 1988 (1. wyd.: 1986)

Dorna M., Między Hilferuf a Lug i Trug - spór o interpretację początków państwa krzyżackiego $w$ Prusach $w$ historiografii XIX i pierwszej połowy XX wieku, Klio Polska. Studia i Materiały z Dziejów Historiografii Polskiej 12 (2020), s. 97-118

Historia Pomorza, t. 1: do roku 1466, red. G. Labuda, Poznań 1969

Jasiński T., Dzieje Zakonu Krzyżackiego w dorobku naukowym Gerarda Labudy, [w: ] Naukowe dzieło Profesora Gerarda Labudy, red. J. Dobosz, Poznań 2006, s. 111$-120$

Kętrzyński W., Der Deutsche Orden und Konrad von Masovien 1225-1235, Lemberg 1904

Kętrzyński W., O powołaniu Krzyżaków przez ks. Konrada, Kraków 1903

Labuda G., Die Anfänge des Deutschen Ordens: In Jerusalem oder in Akkon?, Jahrbuch für die Geschichte Mittel- und Ostdeutschlands 52 (2006), s. 153-172

Labuda G., Die Urkunden über die Anfänge des Deutschen Ordens im Kulmerland und 
in Preußen in den Jahren 1226-1243, [w: ] Die geistlichen Ritterorden Europas, hg. v. J. Fleckenstein, M. Hellmann, Sigmaringen 1980, s. 299-316

Labuda G., Epilog dyskusji o początkach Zakonu Krzyżackiego w ziemi chetmińskiej i w Prusach, [w: ] tegoż, Studia krytyczne o początkach Zakonu Krzyżackiego $w$ Prusach i na Pomorzu. Pisma wybrane, Poznań 2007, s. 271-298

Labuda G., Krzyżacy, [w: ] Encyklopedia Katolicka, t. 10, Lublin 2004, kol. 55-62 Labuda G., O opacie Stanisławie autorze Kroniki Oliwskiej z połowy XIV wieku, Komunikaty Mazursko-Warmińskie 1980, nr 1, s. 3-16

Labuda G., O udziale Krzyżaków i o śmierci wielkiego mistrza Zakonu Krzyżackiego Poppo von Osterna $w$ bitwie $z$ Tatarami pod Legnica $w$ roku 1241, Zapiski Historyczne 47 (1982), z. 4, s. 89-102

Labuda G., O źródłach „Kroniki Pruskiej” Piotra z Dusburga (na marginesie pracy Marzeny Pollakówny, Kronika Piotra z Dusburga), Komunikaty Mazursko-Warmińskie 1971 , nr 2-3, s. 217-243

Labuda G., Podbój Prus w XIII wieku, [w:] Ekspansja niemieckch zakonów rycerskich $w$ strefie Battyku od XIII do połowy XVI wieku. Materiaty z konferencji historyków radzieckich i polskich $w$ Toruniu $z$ r. 1988, red. M. Biskup, Toruń 1990, s. 31-50

Labuda G., Podstawy polityczno-prawne kupna Pomorza Gdańskiego przez Zakon Krzyżacki od margrabiów brandenburskich w latach 1309-1310, Roczniki Historyczne 71 (2005), s. 31-61

Labuda G., Polska i krzyżacka misja w Prusach do połowy XIII wieku, Poznań 1937 (odbitka z Annales Missiologicae 9 [1937], s. 201-435)

Labuda G., Pomorsko-krzyżacki zatarg graniczny z roku 1267/1268. Przyczynek do migracji Prusów na Pomorze Gdańskie, Zapiski Historyczne 50 (1985), z. 2, s. $7-25$

Labuda G., Stanowisko ziemi chetmińskiej w państwie krzyżackim w latach 1228-1454, Przegląd Historyczny 45 (1954), nr 2-3, s. 280-337

Labuda G., Stosunek prawnopubliczny Zakonu Krzyżackiego do Rzeszy Niemieckiej wświetle Złotej Bulli Fryderyka II z roku 1226, Czasopismo Prawno-Historyczne 3 (1951), s. 87-124

Labuda G., Studia krytyczne o początkach Zakonu Krzyżackiego w Prusach i na Pomorzu. Pisma wybrane, Poznań 2007

Labuda G., Studia nad annalistyka pomorska z XIII-XV wieku, Zapiski Towarzystwa Naukowego w Toruniu 20 (1954), z. 1-4, s. 101-138

Labuda G., Über die angeblichen und vermuteten Fälschungen des Deutschen Ordens in Preußen, [w:] Fälschungen im Mittelalter. Internationaler Kongreß der Monumen- 
ta Germaniae Historica München, 16.-19. September 1986, Teil IV Diplomatische Fälschungen (II), Hannover 1988, s. 499-521

Labuda G., Über die Urkunden zur Gründung des Deutschen Ordens im Kulmerlande und im Preussen in den Jahren 1226-1234, [w: Die Ritterorden zwischen geistlicher und weltlicher Macht im Mittelalter, hg. v. Z.H. Nowak, Toruń 1990 (Ordines militares. Colloquia Torunensia Historica V), s. 21-44

Labuda G., W sprawie wydania dokumentów krzyżackich Polsce w 1526 r., Zapiski Historyczne 21 (1955), z. 3-4, s. 184-200

Wrzesiński W., Polskie Ziemie Zachodnie i Pótnocne w historycznej twórczości naukowej Gerarda Labudy, [w:] Naukowe dzieto Profesora Gerarda Labudy, red. J. Dobosz, Poznań 2006, s. 143-159 